\title{
The predator Coenosia Attenuata Stein (Diptera, Muscidae) on cultivated plants from Brazil
}

\author{
MÁRCIA S. COURI ${ }^{1}$, VIVIANE R. DE SOUSA ${ }^{1}$, RAFAEL M. LIMA ${ }^{1}$ and NIVIA S. DIAS-PINI ${ }^{2}$ \\ ${ }^{1}$ Departamento de Entomologia, Museu Nacional, Quinta da Boa Vista, São Cristóvão, 20940-040 Rio de Janeiro, RJ, Brazil \\ ${ }^{2}$ Laboratório de Entomologia, Embrapa Agroindústria Tropical, Rua Dra. Sara Mesquita, 2270, 60511-110 Fortaleza, CE, Brazil
}

Manuscript received on July 16, 2017; accepted for publication on September 11, 2017

\begin{abstract}
Coenosia attenuata Stein (1903) is a predatory fly that is commonly found in greenhouses and open fields preying on whiteflies, leafminers, psocopterans and other insects. The species is widespread in the Old World and its distribution has expanded in recent times to Neotropical countries including Chile, Colombia, Costa Rica, Ecuador and Peru. We report here for the first time the presence of C. attenuata in Brazil, occurring in different sites in the State of Ceará (Northeastern Brazil). Expansion of the distribution range of this muscid to the eastern parts of South America opens up the possibility of applying the beneficial predator as a biological control agent for protected crops of the region.
\end{abstract}

Key words: Biological control, geographical distribution, hunter-fly, natural enemy, tiger-fly.

\section{INTRODUCTION}

The predator fly Coenosia attenuata Stein (1903) (Muscidae, Coenosiinae), commonly known as the tiger-fly or hunter-fly, is widespread in Palaearctic, Afrotropical, Oriental, and Australian regions (Couri and Salas 2010), and its distribution has expanded in recent times to the Nearctic and Neotropical regions. In Central and South America, observations of this species were first reported some 15 years ago and now cover Costa Rica (HernándezRamírez 2008), Ecuador and Peru (MartinezSanchez et al. 2002), Colombia (Pérez 2006) and Chile (Couri and Salas 2010). A redescription of $C$. attenuata and a review of the available European literature relating to the biology and habits of this species are available (Hoebeke et al. 2003).

Correspondence to: Nivia da Silva Dias-Pini

E-mail: nivia.dias@embrapa.br
Tiger-flies are commonly found in greenhouses and open fields. Adults measure 2.5 to $4.0 \mathrm{~mm}$ and exhibit sexual dimorphism whereby the females are slightly larger than the males, grayish in color with darker stripes on the abdomen, while fully the dichoptic males are grayish with yellow legs, brown tarsi and silver lunule and frons (Couri and Salas 2010). Under controlled conditions $\left(25^{\circ} \mathrm{C}\right.$ and $70 \%$ relative humidity), the complete life cycle of C. attenuata takes 26 days with the larval and pupal stages each lasting 10 days (Prieto et al. 2005). Both larvae and adults are polyphagous, preying mainly on whiteflies, leafminer flies, psocopterans and other insects (Mateus 2012). Moreover, according to Ugine et al. (2010), tiger-fly larvae have the capacity to feed on a large numbers of fungus gnats.

In consideration of its feeding behavior, $C$. attenuata is recognized as an effective predator of greenhouse pests with promising application in 
biological control. Martins et al. (2012) investigated the predatory capacity, under laboratory conditions, of the muscid against several insects, including other natural enemies (predators and parasitoids) and pests that commonly attack protected crops, and reported that the tiger-fly was able to kill all of the species tested. In a study of the spatial distribution, flight and predator activities of $C$. attenuata on crops of cucumber, sweet pepper and tomato cultivated in greenhouses, Mateus (2012) found that $59 \%$ of the selected prey were whiteflies and that many flights of the predators were associated with territorial behavior rather than predatory activity. A review article by Pohl et al. (2012) described the presence of the predator for the first time in Turkey and highlighted its importance in the control of greenhouse pests. These authors also reported that $C$. attenuata can not only colonize greenhouses from the outside for short periods but can also complete their developmental cycle in greenhouse soil and become established in situ for protracted periods.

In this paper, we report for the first time the occurrence of $C$. attenuata in Brazil. We found it [or the introduced species] in several localities in the State of Ceará (Northeastern Brazil) in chrysanthemum (Chrysanthemum morifolium Ramat.) and tomato (Solanum lycopersicum L.) crops in greenhouses and a crop of baby's breath flower (Gypsophila paniculata L.) in the open.

\section{MATERIALS AND METHODS}

Muscid flies were captured in November 2016 and January 2017 at three sites in the municipalities of São Benedito and Guaraciaba do Norte, situated in the Serra da Ibiapaba region of Ceará State, northeastern Brazil, approximately $350 \mathrm{~km}$ from the State capital (Fortaleza) (Table I).

Insects were trapped using entomological nets in greenhouses with crops of chrysanthemum (Chrysanthemum morifolium Ramat.) (Figure 1) and tomato (Solanum lycopersicum L.) (Figures 2 and 3 ) and in an open crop of baby's breath flowers (Gypsophila paniculata L.) (Figure 4). Adult flies were preserved in $95 \%$ ethanol and transferred to the Laboratory of Diptera at the Museu Nacional, Universidade Federal do Rio de Janeiro, Rio de Janeiro, RJ, Brazil, where they were mounted on entomological pins and labelled. MC identified the specimens which are now deposited at the collection of Museu Nacional, Universidade Federal do Rio de Janeiro (MN, UFRJ).

\section{RESULTS AND DISCUSSION}

A total of 37 muscid flies, each identified unambiguously as $C$. attenuata, were captured at the three study sites comprising 17 on greenhouse chrysanthemums, 4 on greenhouse tomatoes and 16 on the crop of baby's breath flowers (Table I). The overall frequency of captured females $(65 \%)$ was higher than that of males (35\%).

In crops growing in protected environments, the predation capacity of $C$. attenuata is high for a wide range of prey, although female flies exhibit a probable food preference for whiteflies and the larvae of leafminer flies (Martins et al. 2012). Studies performed in greenhouses with tomato crops revealed that the predation flight activities of $C$. attenuata against whiteflies are influenced by temperature and the level of visibility at the hunting site (Bonsignore 2016). Interestingly, females performed more predatory flights and territorial defense activities in comparison with males.

An important practical issue associated with the potential application of $C$. attenuata as a biological control agent is that of rearing flies in sufficient quantities at reasonable cost. Some progress in this area has been reported recently by Martins et al. (2015), who described a method for rearing muscid flies in the laboratory and established the optimal levels for various critical parameters such as number of rearing cages and 
TABLE I

Summary of specimens of Coenosia attenuata Stein (Diptera, Muscidae) captured in entomological nets placed in greenhouses, protected crop and in an open field site in Northeastern Brazil by Sousa and Braga.

\begin{tabular}{|c|c|c|c|c|}
\hline Crop & Collection site & $\begin{array}{c}\text { Coordinates and } \\
\text { altitude }\end{array}$ & Collection date & $\begin{array}{l}\text { Number of } \\
\text { individuals }\end{array}$ \\
\hline \multirow[t]{2}{*}{$\begin{array}{c}\text { Chrysanthemum morifolium } \\
\text { Ramat }\end{array}$} & \multirow{2}{*}{$\begin{array}{l}\text { São Benedito, } \\
\text { Ceará, Brazil } \\
\text { (greenhouse) }\end{array}$} & \multirow{2}{*}{$\begin{array}{c}04^{\circ} 03^{\prime} 53.6^{\prime \prime} \mathrm{S} \\
40^{\circ} 53^{\prime} 43.4^{\prime \prime} \mathrm{W} \\
889 \mathrm{~m}\end{array}$} & 24.xi.2016 & $4 \hat{O}, 10$ ㅇ \\
\hline & & & 26.i.2017 & $1 \hat{\jmath}, 2$ + \\
\hline Solanum lycopersicum L. & $\begin{array}{c}\text { Guaraciaba do Norte, } \\
\text { Ceará, Brazil } \\
\text { (protected crop) }\end{array}$ & $\begin{array}{c}04^{\circ} 03^{\prime} 53.7^{\prime \prime} \mathrm{S} \\
40^{\circ} 53^{\prime} 43.4^{\prime \prime} \mathrm{W} \\
868 \mathrm{~m}\end{array}$ & 25.i.2017 & $2 \hat{O}, 2$ 우 \\
\hline \multirow[t]{2}{*}{ Gypsophila paniculata L. } & \multirow{2}{*}{$\begin{array}{l}\text { São Benedito, } \\
\text { Ceará, Brazil } \\
\text { (open field) }\end{array}$} & \multirow{2}{*}{$\begin{array}{c}04^{\circ} 03^{\prime} 50.5^{\prime \prime} \mathrm{S} \\
40^{\circ} 53^{\prime} 14.5^{\prime \prime} \mathrm{W} \\
855 \mathrm{~m}\end{array}$} & 24.xi.2016 & $5 \hat{\jmath}, 6$ 우 \\
\hline & & & 26.i.2017 & $1 \hat{\jmath}, 4+$ \\
\hline
\end{tabular}

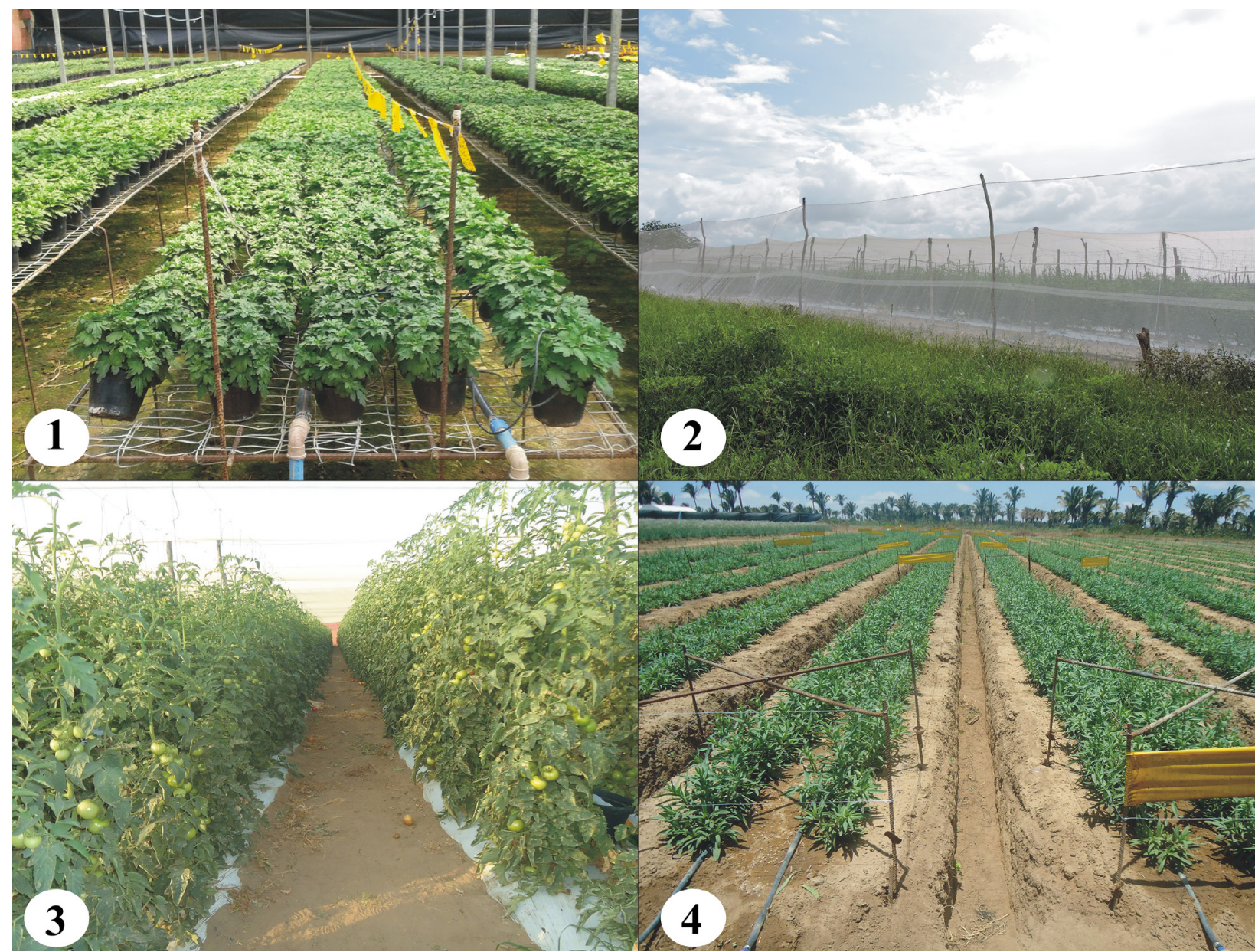

Figure 1 - (1) Image of Chrysanthemum morifolium Ramat. greenhouses; (2) Image of Solanum lycopersicum L. protected crop, external overview of the culture; (3) Image of Solanum lycopersicum L. protected crop, internal view of the culture; (4) Image of Gypsophila paniculata L. open crop. 
adequate substrates for oviposition and rearing of larvae. Such methods may be applicable to other members of the "greenhouse predator community", which includes Coenosia species such as $C$. atra Meigen (1830), C. humilis Meigen (1826), C. strigipes Stein (1916), C. tigrina Fabricius (1775) and C. testacea Robineau-Desvoidy (1830), since they all prey on whiteflies, black fungus gnats and leaf-miner flies and have potential application as biological control agents (Kühne 2000).

Documentation of the presence of $C$. attenuata in Brazil is very important because it demonstrates that the range of the predator has expanded towards the eastern parts of South America. In this context, Seabra et al. (2015) investigated the geographical dispersal patterns of the tiger-fly through phylogenetic studies involving mitochondrial cytochrome oxidase I and nuclear white and elongation factor- $1 \alpha$ genes. According to these authors, the most likely region of origin of the species is the Mediterranean and that colonization of the New World was probably a result of three independent colonization's, one from the Middle East to North America, another from Europe to South America (Chile) and a third from an undetermined origin to South America (Ecuador).

The present new record of Coenosia attenuata reinforces the question about which would be the geographical origin of the populations, for example, how the Chilean populations that came from Europe spread out to the Northeastern of Brazil? This question is, of course, a further question to be analyzed.

The presence of $C$. attenuata in Brazil, described here for the first time, provides an opportunity to study the biology and ecology of this insect in new settings and opens up the possibility of applying the natural predator as a biological control agent for protected crops of the region.

\section{ACKNOWLEDGMENTS}

The authors wish to thank Carlos Augusto Teixeira Braga (Embrapa Agroindústria Tropical) for assisting with the capture of insects. We also thank the anonymous referee for the excellent suggestions that improved this contribution.

\section{REFERENCES}

BONSIGNORE CP. 2016. Environmental factors affecting the behavior of Coenosia attenuata, a predator of Trialeurodes vaporariorum in tomato greenhouses. Entomol Exp Appl 158(1): 87-96.

COURI MS AND SALAS C. 2010. First record of Coenosia attenuata Stein (Diptera, Muscidae) from Chile, with biological notes. Rev Bras Entomol 54(1): 144-145.

HERNÁNDEZ-RAMÍREZ J. 2008. Presencia de la 'mosca tigre' en Costa Rica. In: Monge MMP et al. (Eds), Notable avance en el "Programa de material propagativo sano" (Clear Stock Program). Actualidad Fitosanitaria 33: 3.

HOEBEKE ER, SENSENBACH EJ, SANDERSON JP AND WRAIGHT SP. 2003. First Report of Coenosia attenuata Stein (Diptera: Muscidae), an Old World "Hunter Fly" in North America. Proc Entomol Soc Wash 105(3): 769-775.

KÜHNE S. 2000. Räuberische Fliegen der Gattung Coenosia Meigen, 1826 (Diptera: Muscidae) und die Möglichkeit ihres Einsatzes bei der biologischen Schädlingsbekämpfung. Stud Dipterol Suppl. 9 AmpyxVerlag, Halle (Saale), 78 p.

MARTINEZ-SANCHEZ A, MARCOS-GARCIA MA AND PONT AC. 2002. Coenosia attenuata Stein, 1903 (Diptera, Muscidae) nueva especie para la fauna neotropical. Boll Zool Agrar Bachic 34: 269-272.

MARTINS J, DOMINGOS C, NUNES R, GARCIA A, RAMOS C, MATEUS C AND FIGUEIREDO E. 2012. Coenosia attenuata (Diptera: muscidae): Um predador em estudo para utilização em culturas protegidas. Rev Cienc Agrar 35(2): 229-235.

MARTINS J, MATEUS C, RAMOS AC AND FIGUEIREDO E. 2015. An optimized method for mass rearing the tiger-fly, Coenosia attenuata (Diptera: Muscidae). Eur J Entomol 112(3): 1-7.

MATEUS C. 2012. Bioecology and behaviour of Coenosia attenuata in greenhouse vegetable crops in the Oeste region, Portugal. B Insectol 65(2): 257-263.

PÉREZ MM. 2006. Estudio de la morfología externa de los adultos de la mosca cazadora Coenosia attenuata Stein, 1903 (Diptera: Muscidae), y primer reporte para Colombia. Revista Fac Ciencias B 2: 68-87.

POHL D, KÜHNE S, KARACA I AND MOLL E. 2012. Review of Coenosia attenuata Stein and its first record 
as a predator of important greenhouse pests in Turkey. Phytoparasitica 40(1): 63-68.

PRIETO R, FIGUEIREDO E, MIRANDA C AND MEXIA A. 2005. Coenosia attenuata Stein (Diptera: Muscidae): prospecção e actividade em culturas protegidas em Portugal. Bol Sanid Veg Plagas 31: 39-45.

SEABRA SG ET AL. 2015. Phylogeographical patterns in Coenosia attenuata (Diptera: Muscidae): a widespread predator of insect species associated with greenhouse crops. Biol J Linnean Soc 114(2): 308-326.

UGINE TA, SENSENBACH EJ, SANDERSON JP AND WRAIGHT SP. 2010. Biology and feeding requirements of larval hunter flies Coenosia attenuata (Diptera: Muscidae) reared on larvae of the fungus gnat Bradysia impatiens (Diptera: Sciaridae). J Econ Entomol 103(4): 1149-1158. 